American Journal of Biochemistry and Biotechnology 6 (1): 1-10, 2010

ISSN 1553-3468

(C) 2010 Science Publications

\title{
Recovery of Lead(II) from Aqueous Solutions by Zea mays Tassel Biosorption
}

\author{
${ }^{1}$ Caliphs M. Zvinowanda, ${ }^{1}$ Jonathan O. Okonkwo, ${ }^{2}$ Nana M. Agyei, \\ ${ }^{3}$ Martin Van Staden, ${ }^{3}$ Werner Jordaan and ${ }^{4}$ Boitumelo V. Kharebe \\ ${ }^{1}$ Department of Environmental, Water and Earth Sciences, Faculty of Science, \\ Tshwane University of Technology, Private Bag X680, \\ Pretoria, 0001, South Africa \\ ${ }^{2}$ Department of Chemistry, University of Limpopo, P.O. Box 235, \\ Medunsa, 0204, South Africa \\ ${ }^{3}$ National Metrology Institute of South Africa, Private Bag X34, \\ Lynnwood Ridge, Pretoria, 0040, South Africa \\ ${ }^{4}$ National Food Technology Research Centre, Private Bag 008, Kanye, Botswana
}

\begin{abstract}
Problem statement: Major adsorbent materials used in heavy metal ion removal from polluted aqueous streams are expensive and difficult to regenerate. In this study, the possibility of using Zea mays tassel, as an alternative low cost biosorbent material to remediate heavy metal pollution was investigated. Lead (II) was used because of its wide application in industrial products and well documented toxicity. Approach: Tassel was obtained from mature Zea mays cultivar R52 hybrid plants. The tassel was milled to a powder and was used to adsorb lead(II) ions from simulated solutions in batch experiments. The desorption of lead(II) was carried out using nitric acid and sodium citrate solutions. The adsorbent was characterized by FTIR, EDX and ESCA before and after application of lead(II) solutions. Results: For samples with concentrations of $100 \mathrm{mg} \mathrm{L}^{-1} \mathrm{~Pb}(\mathrm{II}), 94-$ 98\% was adsorbed and 57-74 and 57-67\% recoveries were achieved with 0.5-5 $\mathrm{M}$ nitric acid and 0.01$0.2 \mathrm{M}$ sodium citrate as the stripping solutions, respectively. EDX spectrum of pure tassel indicated that group 1 and 2 metals were the major exchangeable ions present on its surface. ESCA analysis picked up small amounts of lead(II) in the form of $\mathrm{Pb}(\mathrm{OH})^{+}$and $\mathrm{Pb}(\mathrm{NH})^{+}$ions on the surface of tassel adsorbent exposed to $\mathrm{Pb}^{2+}$ ions and none on pure tassel sample. Functional groups such as $-\mathrm{H},-\mathrm{NH}_{2}$, $\mathrm{C}=\mathrm{O}$ and $-\mathrm{COOH}$ which are polar and are legends which are capable of binding heavy metals were identified by FTIR. Conclusion: The potential of Zea mays tassel to adsorb and recover heavy metals from aqueous solution was successfully demonstrated with $\mathrm{Pb}$ (II) sample solutions. The results obtained thus far demonstrated the possibility of using tassel powder in the removal as well as recovery of metals from aqueous solutions.
\end{abstract}

Key words: Removal, recovery, $\mathrm{Pb}(\mathrm{II})$, aqueous solution, maize tassel

\section{INTRODUCTION}

Heavy metals are widely used in processing industries in the form of catalysts, additives, reagents and this has increased their presence in effluent generated from these processes. Since a number of heavy metals such as $\mathrm{Pb}$ have adverse effects on human health, particularly in children, their removal from environmental media is, therefore, necessary (Yurtsever and Sengil, 2009). Their accumulation in humans causes kidney failure, nervous system damage and bone softening as well as other serious illnesses (Wang et al.,
2009). Very low levels of exposure to young children under the age of six can result in reduced IQ, learning disabilities, attention deficit disorders, behavioral problems, stunted growth, impaired hearing. At high levels of exposure, a child may become mentally retarded, fall into coma and even die from lead poisoning. In adults, lead can increase blood pressure and cause fertility problems, muscle and joint pain, irritability and memory and concentration problems (Naiya et al., 2009). Consequently, the removal of heavy metals such as $\mathrm{Pb}(\mathrm{II})$ from aqueous solutions have been reported using materials namely: Natural

Corresponding Author: Caliphs M. Zvinowanda, Department of Environmental, Water and Earth Sciences, Faculty of Science, Tshwane University of Technology, Private Bag X680, Pretoria, 0001, South Africa, Tel: +27 12382 6320, Fax: +27 123826354 
fruit shells (Murathan and Bütün, 2006; Senthilkumaar et al., 2000), rice husk (Wong et al., 2003a; Kumar, 2006), granular ferric hydroxide (Banerjee et al., 2008), coca shells (Meunier et al., 2003), olive cake (Amuda et al., 2007), activated coconut shell (Prasad and Saxena, 2007), natural sericitic pyrophyllite (Demirbas, 2008) and agro-based waste materials (Abia and Igwe, 2005). In particular, biosorbents of plant origin including maize cob, maize husk, among others, have been reported to be good adsorbents for removing metals from aqueous solutions (Abia and Igwe, 2005; Rios et al., 2003). To improve the metal uptake capacities of some of these biosorbents, chemical modification has been employed (Prasad and Saxena, 2007; McSweeny et al., 2006; Chauhan et al., 2006; Nagib et al., 1999; Kobayashi et al., 1990). However, most of the materials being used adsorb metals non-reversibly such that the disposal of the solid waste generated becomes a secondary problem.

The remediation of $\mathrm{Pb}(\mathrm{II})$ in aqueous wastes by adsorption has been reported (Doyurum and Çelik, 2006; Vaughan et al., 2001; Kim, 2004; Keskinkan et al., 2004). The mechanisms of uptake of $\mathrm{Pb}$ (II) and other toxic metals by adsorption have been elucidated by kinetic and thermodynamic studies which gave further insight into how biosorbents work (Naiya et al., 2009; Banerjee et al., 2008; Wong et al., 2003b; Awofulu and Okonkwo, 2005; Igwe et al., 2005). However, most of the publications on the use of natural/agricultural materials as adsorbent for metal removal from aqueous solutions have so far made no attempt to recover metals adsorbed by means of stripping agents. The recovery of $\mathrm{Pb}$ (II) ions from synthetic adsorbents by stripping has been discussed in just few publications (Rosa et al., 2003; Guibal, 2004). The recovery of metals adsorbed is important since this offers the opportunity for recycling metals for possible commercial use. Furthermore, the increasing demand for new and economic processes for the recovery of metal ions from industrial effluents has led many researchers to investigate the possibility of using biosorbents for metal uptake (Gardea-Torresdey et al., 2002).

In this study, we report the removal and recovery of $\mathrm{Pb}$ (II) using Zea mays tassel powder. Surface analysis techniques were applied for the elucidation of functional groups on the surface of tassel and to identify active binding sites that may be responsible for the adsorption of $\mathrm{Pb}$ (II) in aqueous solutions. The present report is part of an ongoing project on the suitability of Zea mays tassel as solid phase extractive material or resin for wastewater treatment. The utilization of tassels for the recovery of metals from effluent solutions would, however, attach some economic value to this waste material that currently has no value. The obvious environmental benefit is the utilization of a waste material, whilst cleaning metal contaminated water and this is of particular relevance to developing countries such as South Africa, which has been classified as water scarce country. This will contribute towards good water quality and waste management in the country.

\section{MATERIALS AND METHODS}

Batch adsorption experiments of lead(II): Six sets (6 samples per set) of simulated $100.0 \mathrm{mg} \mathrm{L}^{-1} \mathrm{~Pb}$ (II) samples of $\mathrm{pH} 4$ were prepared in $100 \mathrm{~mL}$ volumetric flasks and then transferred into $250 \mathrm{~mL}$ Erlenmeyer flasks. To each sample, $1.00 \mathrm{~g}$ of $500 \mu \mathrm{m}$ diameter tassel powder was added and the mixture was then equilibrated at $25 \pm 0.5^{\circ} \mathrm{C}$ for $2 \mathrm{~h}$ in a water bath shaker. The samples were then centrifuged at $2000 \mathrm{rpm}$ for 4 min and the supernatant filtered through $0.45 \mu \mathrm{m}$ membrane filter. A Spectra AA 220 FS Atomic Absorption Spectrometer (Victoria, Australia) with a Varian SIPS pumps linked to a SP S5 Sample preparation system was used for sample analysis. The quantity of $\mathrm{Pb}(\mathrm{II})$ adsorbed $\left(\mathrm{q}_{\mathrm{ea}}\right)$ at equilibrium, was calculated from the following equations:

$$
\begin{gathered}
\mathrm{C}_{\mathrm{a}}=\mathrm{C}_{\mathrm{o}}-\mathrm{C}_{\mathrm{f}} \\
\mathrm{q}_{\mathrm{ea}}=\frac{\mathrm{C}_{\mathrm{o}}-\mathrm{C}_{\mathrm{f}}}{\mathrm{M}_{1}} \cdot \mathrm{V}_{1} \\
\therefore \mathrm{q}_{\mathrm{ea}}=\frac{\mathrm{C}_{\mathrm{a}}}{\mathrm{M}_{1}} \cdot \mathrm{V}_{1}
\end{gathered}
$$

Where:

$\mathrm{q}_{\mathrm{ea}}\left(\mathrm{mg} \mathrm{g}^{-1}\right)=$ Quantity of $\mathrm{Pb}(\mathrm{II})$ adsorbed

$\mathrm{C}_{\mathrm{o}}\left(\mathrm{mg} \mathrm{L}^{-1}\right)=$ The initial $\left[\mathrm{Pb}^{2+}\right]$ in sample

$\mathrm{C}_{\mathrm{f}}\left(\mathrm{mg} \mathrm{L}^{-1}\right)=$ Final $\left[\mathrm{Pb}^{2+}\right]$ in the adsorption filtrate

$\mathrm{C}_{\mathrm{a}}\left(\mathrm{mg} \mathrm{L}^{-1}\right)=$ The apparent $\left[\mathrm{Pb}^{2+}\right]$ adsorbed

$\mathrm{V}_{1}(\mathrm{~L}) \quad=$ The volume of sample treated with tassel

$\mathrm{M}_{1} \quad=$ The mass of adsorbent added to the sample

The residue was then kept for investigation in recovery experiments.

Batch recovery experiments of lead(II): The residue materials collected from previous section were each rinsed thoroughly with deionised water and then oven dried at $105 \pm 2{ }^{\circ} \mathrm{C}$ for $12 \mathrm{~h}$. The residue material portions were weighed individually and then divided into triplicates. One set made up of six triplicates was then transferred into $250 \mathrm{~mL}$ Erlenmeyer flask, to which $100.0 \mathrm{~mL}$ of $0.5,1.0,2.0,3.0,4.0$ and $5.0 \mathrm{M}$ $\mathrm{HNO}_{3(\mathrm{aq})}$ was added to each triplicate. The second set 
was stripped using $0.01,0.02,0.05,0.10,0.15$ and 0.20 $\mathrm{M}$ sodium citrate solutions. The mixtures were then equilibrated for $2 \mathrm{~h}$ at $25 \pm 0.5^{\circ} \mathrm{C}$ before centrifuging at $2000 \mathrm{rpm}$ for $4 \mathrm{~min}$. The supernatant was then filtered through a $0.45 \mu \mathrm{m}$ membrane. The concentration of $\mathrm{Pb}$ (II) in the leachate was determined using FAAS. The quantity of $\mathrm{Pb}(\mathrm{II})$ recovered $\left(\mathrm{q}_{\mathrm{er}}\right)$ from the adsorbent was calculated according to the following equation:

$$
\mathrm{q}_{\mathrm{er}}=\frac{\mathrm{C}_{1}}{\mathrm{M}_{2}} \cdot \mathrm{V}_{2}
$$

Where:

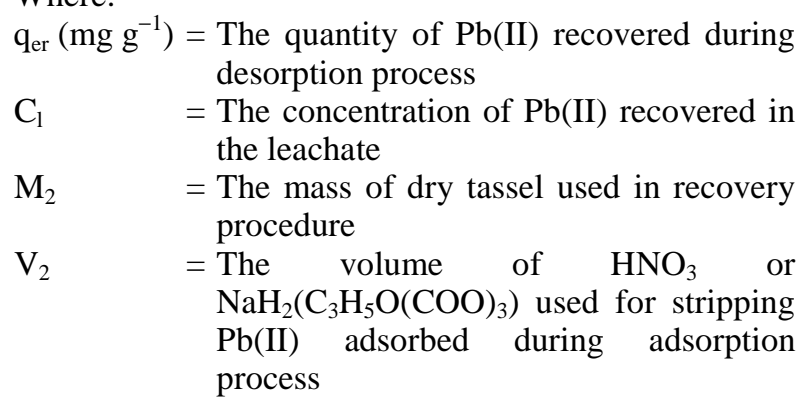

The percentage recovery obtained after stripping of adsorbed $\mathrm{Pb}$ (II) was calculated using Eq. 5-7:

$$
\begin{aligned}
& \mathrm{R}=\frac{\mathrm{C}_{1}}{\mathrm{C}_{\mathrm{o}}-\mathrm{C}_{\mathrm{f}}} \cdot \frac{\mathrm{M}_{1}}{\mathrm{M}_{2}} \cdot \frac{\mathrm{V}_{2}}{\mathrm{~V}_{1}} \cdot 100 \\
& \therefore \mathrm{R}=\frac{\mathrm{C}_{1}}{\mathrm{C}_{\mathrm{a}}} \cdot \frac{\mathrm{M}_{1}}{\mathrm{M}_{2}} \cdot \frac{\mathrm{V}_{2}}{\mathrm{~V}_{1}} \cdot 100
\end{aligned}
$$

As described previously, the concentration of $\mathrm{Pb}$ (II) recovered was determined by means of FAAS.

Electron Spectroscopy for Chemical Analysis (ESCA) of tassel: ESCA was used to determine the surface composition of the tassels before and after metal absorption. The analysis depth was typically about $10 \mathrm{~nm}$ and the detection limit was approximately $0.1 \%$. The powdered samples were analyzed with a PHI Quantum 2000 scanning ESCA microprobe (Physical Electronics, Eden Prairie). The samples were mounted on sticky paper and inserted into the vacuum system at a base pressure $<10^{-8}$ Torr. Monochromatic Al K-alpha $\mathrm{x}$-rays at $20 \mathrm{~W}$ were used to illuminate the samples and the binding energy spectra were acquired at pass energy of $117.4 \mathrm{eV}$ for the wide scans and $29.35 \mathrm{eV}$ for the narrow scans. From the wide scans, the elemental concentrations were determined by measuring the peak areas and the manufacturer's sensitivity factors. The chemical composition was determined from the narrow scans.

Energy Dispersive X-ray analysis (EDX) of tassel: EDX analysis of tassel powder was carried out on JSM $5800 \mathrm{LV}$, Vantage 6, Analytical Systems with $130 \mathrm{eV}$ detector (JEOL, Tokyo, Japan). The EDX was carried out in order to characterize the metal distribution on the surface of the tassel. A small amount of powder was spread on the sample stage coated with gold. The sample was then bombarded with electrons accelerated by $20 \mathrm{keV}$ power supply at a take off angle of $35^{\circ}$ in order to get an EDX spectrum.

FTIR analysis of tassel: A Perkin-Elmer GX2000 FTIR spectrometer adapted with Perkin-Elmer Auto Image Microscope System was used in the identification of the functional groups that may be responsible for adsorption of metal ions on tassel surface. The pure tassel and tassel with $\mathrm{Pb}$ (II) samples were first dried at $105248^{\circ} \mathrm{C}$ for $16 \mathrm{~h}$ and then stored in a desiccator. The dry samples were then diluted to 5\% in $\mathrm{KBr}$ and cast into disks before FTIR analysis.

\section{RESULTS}

Batch experiments for adsorption and recovery of

\begin{tabular}{|c|c|c|c|c|c|c|}
\hline & \multicolumn{5}{|c|}{$\mathrm{HNO}_{3}\left(\mathrm{~mol} \mathrm{~L}^{-1}\right)$} & \multirow[b]{2}{*}{5.0} \\
\hline & 0.5 & 1.0 & 2.0 & 3.0 & 4.0 & \\
\hline $\mathrm{C}_{\mathrm{o}}\left(\mathrm{mg} \mathrm{L}^{-1}\right)$ (initial) & $100.00 \pm 0.10$ & $100.00 \pm 0.10$ & $100.00 \pm 0.10$ & $100.00 \pm 0.10$ & $100.00 \pm 0.10$ & $100.00 \pm 0.10$ \\
\hline $\mathrm{C}_{\mathrm{a}}\left(\mathrm{mg} \mathrm{L}^{-1}\right)$ (adsorbed) & $98.01 \pm 1.10$ & $94.82 \pm 1.10$ & $97.68 \pm 0.71$ & $97.41 \pm 0.71$ & $97.63 \pm 1.80$ & $98.22 \pm 1.70$ \\
\hline $\mathrm{C}_{\mathrm{l}}\left(\mathrm{mg} \mathrm{L}^{-1}\right)$ (leached) & $49.25 \pm 0.50$ & $63.58 \pm 0.40$ & $62.38 \pm 0.00$ & $63.06 \pm 0.80$ & $66.32 \pm 0.80$ & $62.74 \pm 0.80$ \\
\hline $\mathrm{R}(\%)$ (desorbed) & $50.25 \pm 0.03$ & $67.05 \pm 0.01$ & $63.86 \pm 0.01$ & $64.74 \pm 0.60$ & $67.93 \pm 0.02$ & $63.88 \pm 0.03$ \\
\hline
\end{tabular}
$\mathbf{P b}$ (II): The results of batch experiments of $\mathrm{Pb}$ (II) removal and recovery from simulated samples are shown in Table 1-4. Nitric acid in the concentration range of 1.0-5.0 $\mathrm{M}$ gave recoveries between $64-67 \%$. For the second cycle of re-stripping of the lead adsorbed on the tassel, $1.0 \mathrm{M} \mathrm{HNO}_{3}$ was then chosen as the optimum concentration for the stripping exercise. The second cycle of stripping managed to recover on average, $7.0 \%$ of lead which was still remaining after the first cycle of stripping. A linear plot, with $\mathrm{R}^{2}$ of 0.988 was observed as shown in Fig. 1 .

Table 1: The recovery of $\mathrm{Pb}(\mathrm{II})$ from tassel using $\mathrm{HNO}_{3}$ as stripping agent 
Am. J. Biochem. \& Biotech., 6 (1): 1-10, 2010

Table 2: Recovery of $\mathrm{Pb}(\mathrm{II})$ in the second cycle by $1.0 \mathrm{M} \mathrm{HNO}_{3}$ as stripping agent

\begin{tabular}{lrrrrrr}
\hline Sample & \multicolumn{1}{c}{1} & \multicolumn{1}{c}{3} & \multicolumn{1}{l}{4} & \multicolumn{1}{l}{5} & \multicolumn{1}{l}{. } \\
\hline $\mathrm{C}_{\mathrm{a}} / \mathrm{mg} \mathrm{L}^{-1}$ & $48.76 \pm 1.3$ & $31.24 \pm 1.6$ & $35.30 \pm 1.3$ & $34.35 \pm 1.3$ & $31.31 \pm 2.2$ & $35.48 \pm 1.9$ \\
$\mathrm{C}_{\mathrm{l}} / \mathrm{mg} \mathrm{L}^{-1}$ & $3.47 \pm 1.5$ & $2.19 \pm 1.9$ & $2.70 \pm 1.6$ & $1.86 \pm 1.8$ & $1.73 \pm 2.6$ & $2.08 \pm 2.1$ \\
Recovery (\%) & $7.12 \pm 3.9$ & $7.01 \pm 7.9$ & $7.65 \pm 5.3$ & $5.41 \pm 8.6$ & $5.53 \pm 13.7$ & $5.86 \pm 9.0$ \\
\hline
\end{tabular}

": 2nd cycle conditions $\left(25.5^{\circ} \mathrm{C} ; 5 \mathrm{~h}\right.$ contact time); where $\mathrm{C}_{\mathrm{a}}$ is the concentration of $\mathrm{Pb}$ (II) on adsorbent surface left after first cycle, $\mathrm{C}_{\mathrm{l}}$ is the concentration of $\mathrm{Pb}$ (II) in the leachate in second cycle

Table 3: The recovery of $\mathrm{Pb}(\mathrm{II})$ from tassel using $\mathrm{NaH}_{2}\left(\mathrm{C}_{3} \mathrm{H}_{5} \mathrm{O}(\mathrm{COO})_{3}\right)$ as stripping agent

\begin{tabular}{|c|c|c|c|c|c|c|}
\hline & \multicolumn{6}{|c|}{ Citrate $\left(\mathrm{mol} \mathrm{L}^{-1}\right)$} \\
\hline & 0.01 & 0.02 & 0.05 & 0.10 & 0.15 & 0.20 \\
\hline$\overline{\mathrm{C}_{\mathrm{o}}\left(\mathrm{mg} \mathrm{L}^{-1}\right)}$ & $100.00 \pm 0.1$ & $100.00 \pm 0.1$ & $100.00 \pm 0.1$ & $100 \pm 0.1$ & $100.00 \pm 0.1$ & $100.00 \pm 0.01$ \\
\hline $\mathrm{C}_{\mathrm{a}}\left(\mathrm{mg} \mathrm{L}^{-1}\right)$ & $94.84 \pm 0.5$ & $97.83 \pm 1.9$ & $93.85 \pm 0.7$ & $97.86 \pm 2.0$ & $93.64 \pm 1.3$ & $97.42 \pm 1.4$ \\
\hline $\mathrm{C}_{\mathrm{l}}\left(\mathrm{mg} \mathrm{L}^{-1}\right)$ & $9.02 \pm 0.6$ & $14.11 \pm 0.8$ & $14.66 \pm 0.6$ & $23.65 \pm 0.4$ & $28.14 \pm 0.7$ & $36.94 \pm 0.2$ \\
\hline
\end{tabular}

Where $\mathrm{C}_{\mathrm{o}}, \mathrm{C}_{\mathrm{a}}$ and $\mathrm{C}_{\mathrm{l}}$ are $\mathrm{Pb}(\mathrm{II})$ initial, adsorbed and leached concentrations

Table 4: Recovery of $\mathrm{Pb}(\mathrm{II})$ in the second cycle by $0.2 \mathrm{M}$ sodium citrate as stripping agent

\begin{tabular}{lllllll}
\hline Sample & 7 & 8 & 9 & 10 & 11 & 12 \\
\hline $\mathrm{C}_{\mathrm{a}} / \mathrm{mg} \mathrm{L}^{-1}$ & $85.82 \pm 0.9$ & $80.73 \pm 2.2$ & $80.18 \pm 0.9$ & $71.19 \pm 2.1$ & $66.70 \pm 2.0$ & $57.90 \pm 1.7$ \\
$\mathrm{C}_{\mathrm{l}} / \mathrm{mg} \mathrm{L}^{-1}$ & $40.37 \pm 2.2$ & $33.15 \pm 0.8$ & $30.38 \pm 1.4$ & $27.57 \pm 0.7$ & $21.91 \pm 0.9$ & $17.05 \pm 0.4$ \\
\hline
\end{tabular}

*: 2nd cycle conditions $\left(25.5^{\circ} \mathrm{C} ; 5\right.$ h contact time); where $\mathrm{C}_{\mathrm{a}}$ and $\mathrm{C}_{\mathrm{l}}$ are $\mathrm{Pb}(\mathrm{II})$ concentrations left on adsorbent in first cycle and $\mathrm{C}_{\mathrm{l}}$ is the leached one in the second cycle

Table 5: Percentage of elements determined on the surface of tassel powder with and without $\mathrm{Pb}$

\begin{tabular}{lcl}
\multicolumn{3}{c}{ powder with and without $\mathrm{Pb}$} \\
Element & $\begin{array}{l}\text { Pure tassel } \\
(\%) \text { concentration }\end{array}$ & $\begin{array}{l}\text { Used tassel } \\
(\%) \text { concentration }\end{array}$ \\
\hline $\mathrm{C}$ & 81.5 & 81.0 \\
$\mathrm{O}$ & 15.5 & 16.4 \\
$\mathrm{~N}$ & 1.5 & 1.8 \\
$\mathrm{Si}$ & 1.0 & 0.5 \\
$\mathrm{Ca}$ & 0.4 & 0.2 \\
$\mathrm{~Pb}$ & $\mathrm{Nil}$ & $<0.1$ \\
\hline
\end{tabular}

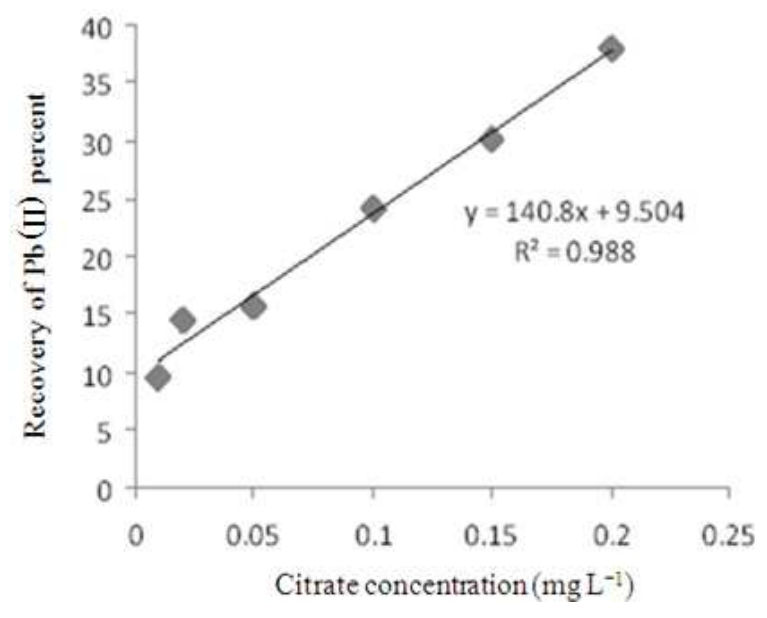

Fig. 1: Plot of lead recovery with $\left.\mathrm{NaH}_{2} \mathrm{C}_{3} \mathrm{H}_{5} \mathrm{O}(\mathrm{COO})_{3}\right)$ solution

In the second cycle of re-leach, $0.20 \mathrm{M}$ citrate solution was used and a further recovery of between $30-$ $47 \%$ was realized.

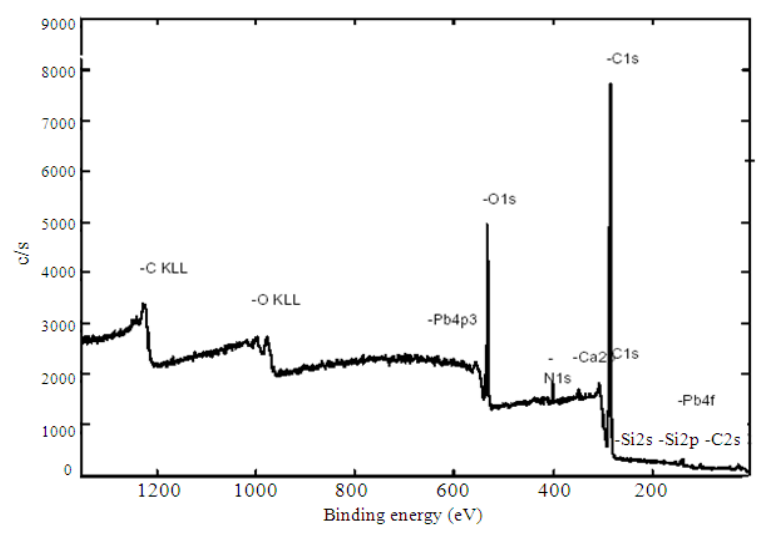

Fig. 2: The ESCA survey scan of used tassel

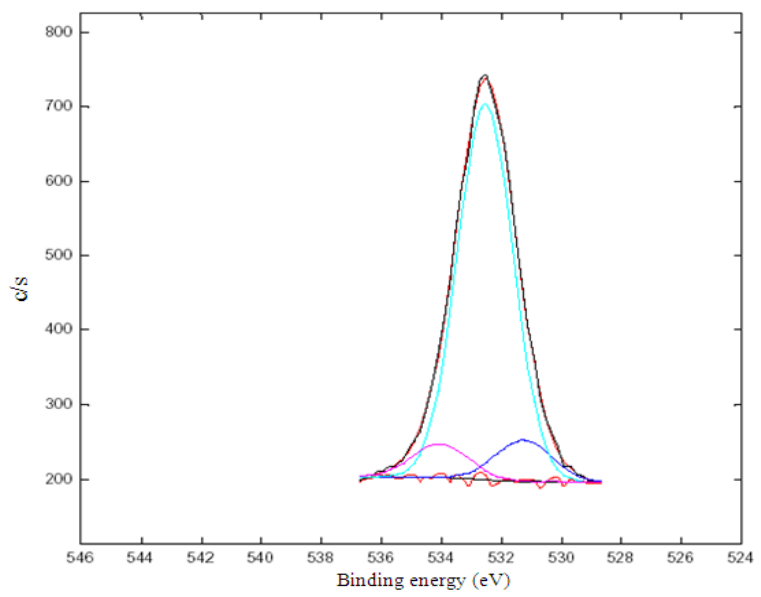

Fig. 3: Os1 XPS spectrum of tassels without lead absorbed 


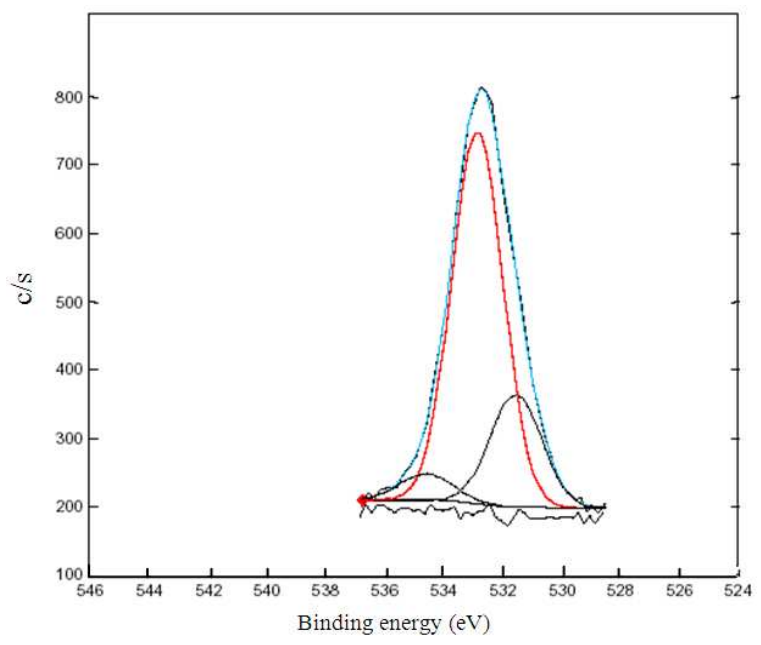

Fig. 4: Os1 XPS spectrum of tassels with Pb absorbed

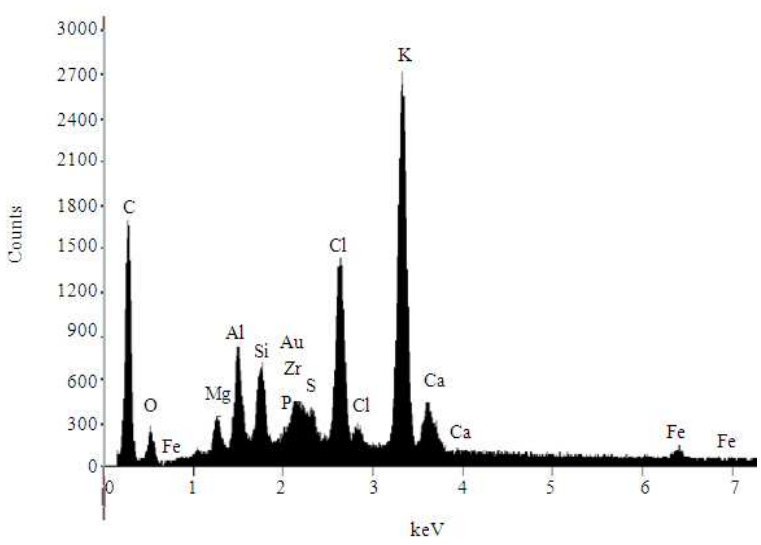

Fig. 5: EDX spectrum of pure tassel powder

ESCA analysis of pure and used tassel: Two tassel powder samples were investigated with ESCA, both consisting of 150-300 micron particles. One sample was pure tassel and the other was used tassel, i.e., tassel that had been used to adsorb $\mathrm{Pb}(\mathrm{II})$.

EDX analysis of pure tassel: The EDX spectrum of pure tassel shows generally elements which are commonly found in plant cells. These include $\mathrm{C}, \mathrm{K}$, $\mathrm{Mg}, \mathrm{Ca}, \mathrm{S}, \mathrm{P}, \mathrm{O}$ and $\mathrm{Cl}$. The presence of $\mathrm{Au}$ and $\mathrm{Zr}$ can be attributed to the stage where the sample was pasted since it was gold plated (Fig. 5). The major elements by weight found in the material were $\mathrm{K}(46 \%), \mathrm{Cl}(21 \%)$, $\mathrm{Al}(10 \%), \operatorname{Si}(9 \%)$ and $\mathrm{Mg}(4 \%)$ and the rest of the elements were less than $3 \%$ by weight (Table 6 ).

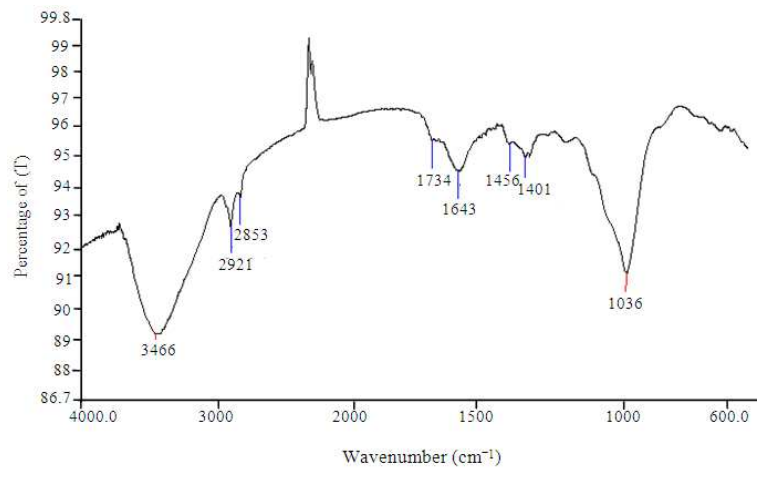

Fig. 6: FTIR of pure tassel powder

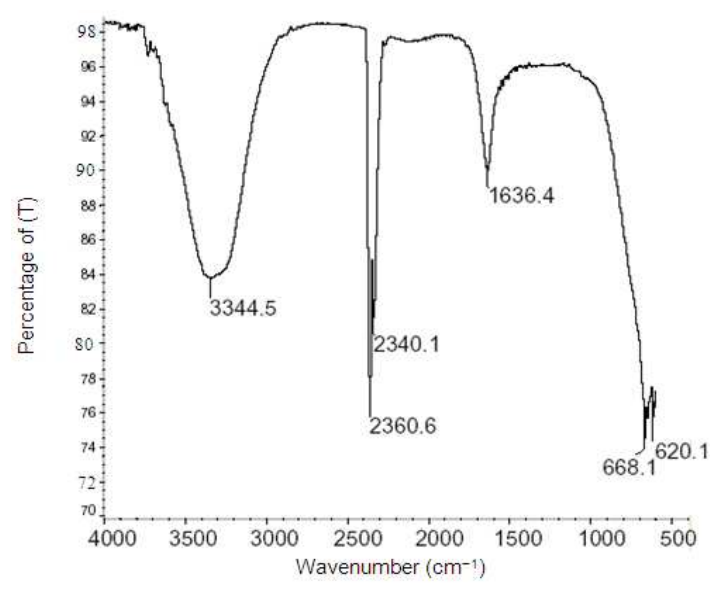

Fig. 7: FTIR of used tassel

FTIR analysis of pure and used tassel: The pure tassel (Fig. 6) shows the presence of the following functional groups $\mathrm{O}-\mathrm{H}$ stretching vibrations (3466), C$\mathrm{C}-\mathrm{H}$ stretching vibrations(2921, 2853), C-H first stretch overtone $(1734 ; 1643), \quad \mathrm{CH}_{2}$ bending (1456;1401);C-O valence vibration (1036). The spectrum for used tassel as shown in Fig. 7 shows the presence of $\mathrm{O}-\mathrm{H}$ stretching vibrations $(3344.5,2360.6)$, (2340.1), (1636.4), $\mathrm{C}=\mathrm{O}$ and $\mathrm{COOH}$ overtones (668.1, 620.1).

Comparison of Zea mays tassel and other biosorbents: The performance of Zea mays tassel as an adsorbent material for heavy metals is compared with other biomass sorbent in Table 6. Tassel has the highest Langmuir monolayer adsorption capacity when compared to other biosorbents listed in the Table 6. 
Am. J. Biochem. \& Biotech., 6 (1): 1-10, 2010

Table 6: Overview summary of selected studies on metal sorption by biosorbents

\begin{tabular}{|c|c|c|c|c|c|c|}
\hline Metal & Biosorbent & Time $\mathrm{h}^{-1}$ & Optimum conditions & $\mathrm{R}(\%)$ & $\mathrm{Q}_{\mathrm{e}} \mathrm{mg} \mathrm{g}^{-1}$ & Reference \\
\hline $\begin{array}{l}\mathrm{Pb}, \mathrm{Cr} \mathrm{Cd}, \\
\mathrm{Cu} \mathrm{Ni}, \mathrm{Al}\end{array}$ & Cocoa shells & $<2$ & $\mathrm{pH} 2 ; 22^{\circ} \mathrm{C}$ & $95 \mathrm{~Pb}$ & $6.2 \mathrm{~Pb}$ & (Meunier et al., 2003) \\
\hline $\mathrm{Zn}^{2+}$ & $\begin{array}{l}\text { Modified } \\
\text { activated carbon }\end{array}$ & 2 & $\mathrm{pH} 2-6$ & 93 & 60.41 & (Amuda et al., 2007) \\
\hline $\begin{array}{l}\mathrm{Pb}^{2+} \\
\mathrm{Cd}^{2+}\end{array}$ & Olive cake & $1 / 2-1$ & $\begin{array}{l}\text { pH } 6 \\
\text { pH } 4.5\end{array}$ & $\begin{array}{l}96.92 \\
82.9\end{array}$ & $\begin{array}{l}19.53 \\
10.56\end{array}$ & (Doyurum and Çelik, 2006) \\
\hline $\begin{array}{l}\mathrm{Cu}^{2+} \\
\mathrm{Pb}^{2+}\end{array}$ & $\begin{array}{l}\text { Modified } \\
\text { rice husk }\end{array}$ & & $5-25 \mathrm{~mL} \mathrm{~min}^{-1}$ & 99.95 & 14.68 & (Wong et al., 2003b) \\
\hline & & & & 99.16 & 48.92 & \\
\hline $\mathrm{Pb}^{2+}$ & Hop & & $\mathrm{pH} 2-6$ & 99 & 74.2 & (Gardea-Torresdey et al., 2002) \\
\hline $\mathrm{Cu}$ & Tea waste & $1 / 4-1 / 3$ & $\mathrm{pH} 5-6$ & 90 & 48 & (Amarasinghe and Williams, 2007) \\
\hline $\mathrm{Pb}$ & & & & & 65 & \\
\hline $\mathrm{Cd}^{2+}$ & Olive cake & 2 & $\begin{array}{l}\mathrm{pH} 6 \\
28-45^{\circ} \mathrm{C}\end{array}$ & 66 & 65.4 & (Al-Anber and Matouq, 2008) \\
\hline $\mathrm{Cd}^{2+}$ & Bean peel & & $\mathrm{pH} 4$ & & 147.71 & \\
\hline & $\begin{array}{l}\text { Peas peel } \\
\text { Fig leaves }\end{array}$ & 4 & $\mathrm{pH} 4.5$ & & 118.91 & (Benaissa, 2006) \\
\hline $\mathrm{Cd}$ & Starfish & & pH 6 & $<50$ & 0.57 & (Choi et al., 2008) \\
\hline $\mathrm{Pb}$ & P. putida & 2 & & $<50$ & 0.73 & \\
\hline $\mathrm{U}(\mathrm{VI})$ & & & & 88.4 & 1.14 & \\
\hline $\mathrm{Pb}^{2+}$ & & & & & 40 & \\
\hline $\mathrm{Cr}^{3+}$ & peat & & $\mathrm{pH} 4.1$ & & 13 & (Koivula et al., 2009) \\
\hline $\mathrm{Cu}^{2+}$ & & & & & 8.4 & \\
\hline As (III) & & & & & 0.06 & \\
\hline $\mathrm{Cd}^{2+}$ & & & & & 83.5 & \\
\hline $\begin{array}{l}\mathrm{Cu}^{2+} \\
\mathrm{Pb}^{2+}\end{array}$ & Marine alga & 2 & $\mathrm{pH} 6$ & & $\begin{array}{l}85-94 \\
227-243\end{array}$ & (Feng and Aldrich, 2004) \\
\hline $\mathrm{Pb}^{2+}$ & Tree fern & 1 & & & 40 & (Ho et al., 2004) \\
\hline $\mathrm{Cr}^{6+}$ & Jute fiber & $10 \mathrm{~min}$ & $\mathrm{pH} 3$ & 95 & 62.9 & (Kumar et al., 2008) \\
\hline $\mathrm{Cd}^{2+}$ & P. sanguineus & 4 & $\mathrm{pH} 6$ & 79 & 3.32 & (Mashitah et al., 2007) \\
\hline $\mathrm{Cd}^{2+}$ & Sugar beet pulp & 1 & pH 5.3 & $70-75$ & 46.1 & (Pehlivan et al., 2007) \\
\hline $\mathrm{Pb}^{2+}$ & & & & 70 & 43.5 & \\
\hline $\mathrm{Pb}^{2+}$ & & & & 98 & & \\
\hline $\mathrm{Cu}^{2+}$, & Neem oil cake & & $\mathrm{pH} 4$ & 92 & $54.9 \mathrm{~Pb}$ & (Rao and Khan, 2007) \\
\hline $\mathrm{Cd}^{2+}$ & & & & 95.7 & & \\
\hline $\mathrm{Cu}$ & Chitosan coated & 4-Mar & $\mathrm{pH} 4$ & $64-94$ & 87.9 & (Popuri et al., 2009) \\
\hline $\mathrm{Ni}$ & PVC & & pH 5 & & 120.5 & \\
\hline $\begin{array}{l}\mathrm{Pb}, \mathrm{Cr}, \mathrm{V} \\
\mathrm{Sr}, \mathrm{Se}, \mathrm{U}\end{array}$ & $\begin{array}{l}\text { Tassel (previous } \\
\text { study) }\end{array}$ & 2-Jan & $\mathrm{pH} 3$ & $47-100$ & $333.4 \mathrm{~Pb}$ & (Zvinowanda et al., 2009b) \\
\hline $\mathrm{Cr}(\mathrm{VI})$ & Tassel (previous & 2-Jan & $\mathrm{pH} 3$ & 89 & & (Zvinowanda et al., 2009c) \\
\hline $\mathrm{Cd}(\mathrm{II})$ & study) & & $\mathrm{pH} 4$ & 87 & & \\
\hline $\mathrm{Pb}^{2+}$ & $\begin{array}{l}\text { Tassel (previous } \\
\text { study) }\end{array}$ & 4-Feb & $\mathrm{pH} 4$ & 87 & & (Zvinowanda et al., 2008b) \\
\hline $\mathrm{Pb}(\mathrm{II})$ & Tassel (this study) & 2-Jan & $\mathrm{pH} 3-4$ & $94-98$ & & \\
\hline
\end{tabular}

\section{DISCUSSION}

The poor recovery of $\mathrm{Pb}(\mathrm{II})$ ions during stripping in the second cycle could be attributed to the existence of some strong active binding sites on or inside the tassel matrix (chemisorptions interactions) between $\mathrm{Pb}$ (II) ions and some of the functional groups on the surface of tassel. Tassel has a high absorption ratio of water and this could possibly create channels where ions could be logged in but find it difficult to come out during stripping process. Furthermore, the trapping of $\mathrm{Pb}$ (II) ions within the "pseudo pores" formed as a result of the aggregation of the tassel particles, may have contributed to the poor recovery. The existence of real pores is ruled out since SEM and BET studies of tassel have shown that tassel powder is mesoporous (Zvinowanda et al., 2008a; 2009a). The total recovery of $\mathrm{Pb}$ (II) ions by sodium citrate as a stripping reagent achieved $57-67 \%$ for the two cycles for solutions in the concentration range of $0.0-10.20 \mathrm{M}$ citrate. An interesting observation was that in this concentration range, the recovery was directly proportional to the stripping reagent concentration.

The possibility of achieving higher recoveries with sodium citrate solution as a stripping reagent may be extrapolated from the linear graph obtained. Modeling from the equation of the relationship of recovery of $\mathrm{Pb}$ (II) and the concentration of the sodium citrate 
solution used, suggested that a $100 \%$ recovery can be achieved by using $0.65 \mathrm{M}$ citrate solution. Rosa et al. (2003) reported $99 \%$ recovery of the bound $\mathrm{Pb}(\mathrm{II})$ ions after exposing the metal laden hop biomass to $0.50 \mathrm{M}$ sodium citrate. In the same report, the recovery of bound $\mathrm{Pb}(\mathrm{II})$ from hydrolyzed hops biomass using 0.1 $\mathrm{M} \mathrm{HCl}$ afforded 85 and $86 \%$ desorption for stems and leaves respectively; while recovery from the esterified hops biomass afforded $25 \%$ desorption for leaves and $29 \%$ for stems. It has also been reported that the recovery of $\mathrm{Pb}$ (II) on a myxococcus xanthus biomass as adsorbent gave $92 \%$ desorption with $0.20 \mathrm{M}$ sodium citrate solution (Hinterstoisser et al., 2001). From the present study, it was observed that the strength of interaction forces between the metal species and the functional groups on the surface of the adsorbent (Zvinowanda et al., 2009a) played a major role in determining the percentage recovery obtained. Results from the present study and our previous reported study on tassel are fairly comparable in terms of tassel performance as a biosorbents as well as the reversibility of the adsorption process with those reported by other researchers (Table 6).

As can be seen in Table 5, the percentage concentrations of all the elements showed a small difference between the two samples which can most likely be explained within experimental errors and homogeneity, except for the small amount of $\mathrm{Pb}$ that was present on the used sample. This ESCA surface data only relates to chemical information from the top $10 \mathrm{~nm}$ of the tassel powders. Figure 2-4 represent the ESCA survey scan and the Pbf and the noise spectra from used tassel material respectively. Because the $\mathrm{Pb}$ peak is so small and close to the detection limit of ESCA, no accurate chemical information could be obtained from the $\mathrm{Pb}$ peak. However, the energy profiles depicts that the active sites where $\mathrm{Pb}^{2+}$ ions are located on the surface of the tassel are in the form of $\mathrm{Pb}(\mathrm{OH})^{+}$and $\mathrm{Pb}(\mathrm{NH})^{+}$. The hydroxyl and the amine groups identified by the FTIR analysis could be possibly linked to the ESCA results. The elements which are in high quantities in the powder are easily exchangeable by heavy metals which have low lying $d$ and $\mathrm{f}$ orbitals. The sites on tassel surface holding up these exchangeable metal ions can then act as active sites for the exchange of heavy metals. The tough fibrous nature of tassel may be attributed to the presence of $\mathrm{Al}$ and $\mathrm{S}$ organometallic polymers.

Vibration shift was observed for the possible $\mathrm{O}-\mathrm{H}$, $\mathrm{N}-\mathrm{H}$ absorption peaks. This could be possibly attributed to the interaction of the functional group with metal ions. The two peaks in the $2800-2900 \mathrm{~cm}^{-1}$ region observed in the pure samples disappear in the used tassel spectrum. Another spectral shift is observed in the $1600-1700 \mathrm{~cm}^{-1}$ region. The spectrum for used tassel has only one peak observed in this region while the pure tassel has two. In the finger print region, 600$1000 \mathrm{~cm}^{-1}$, the spectra of used and pure tassel exhibited two and one peaks respectively. Observations from similar cellulosic compound have been reported (Abia, and Igwe, 2005; Ali et al., 2001; Soudais et al., 2007).

\section{CONCLUSION}

The applicability of tassel as an adsorbent with potential to be regenerated after use was demonstrated. Tassel proved to have a high adsorption capacity for $\mathrm{Pb}$ (II) ions and the stripping process with either sodium citrate or nitric acid proved to be viable. The identification of functional groups such as $-\mathrm{OH},-\mathrm{C}=\mathrm{O}$ and $-\mathrm{COOH}$ on the surface of tassel powder opens another avenue for possible derivatisation of the material to further improve its adsorption capacity for other base metal ions. he information furnished by the EDX spectrum of pure tassel managed to give an insight on the naturally present exchangeable ions, $\mathrm{Na}^{+}$, $\mathrm{K}^{+}, \mathrm{Mg}^{2+}$ and $\mathrm{Ca}^{2+}$ which can undergo competitive adsorption process for the active sites on the tassel surface with $\mathrm{Pb}(\mathrm{II})$ ions. The information observed from FTIR spectral data has shown that the $-\mathrm{OH}$ and possibly the $-\mathrm{NH}_{2}$ groups were present on the surface of tassel and may have been responsible for the uptake of $\mathrm{Pb}$ (II) ions on the tassel. These functional groups are known to act as very active legends and therefore, tend to bind readily with metals ions. The current research has demonstrated the potential of tassel powder to adsorb $\mathrm{Pb}(\mathrm{II})$ ion from aqueous solution and the same time allows for the desorption of the metal. However, further study needs to be done to fully elucidate the mechanisms of adsorption and desorption of heavy metal ions such as $\mathrm{Pb}$ (II) by this novel adsorbent. ESCA analysis managed to identify some of the active sites present on the surface of tassel responsible for metal ion binding. The low surface density of $\mathrm{Pb}^{2+}$ ions identified by ESCA could imply that tassel has internal channels which it uses to adsorb metal ions and were below the zone sampled during the analysis.

\section{ACKNOWLEDGEMENT}

The researchers would like to acknowledge financial support from Tshwane University of Technology and National Research Foundation (IRDP), South Africa. The provision of facilities by the National Metrology Institute of South Africa (NMISA) for the ESCA analysis of tassel samples is greatly appreciated. 


\section{REFERENCES}

Abia, A.A. and J.C. Igwe, 2005. Sorption kinetics and intra-particulate diffusivities of $\mathrm{Cd}, \mathrm{Pb}$ and $\mathrm{Zn}$ ions on maize cob. Afr. J. Biotechnol., 4: 509-512. http://www.academicjournals.org/IJPS/

Al-Anber, Z.A. and M.A.D. Matouq, 2008. Batch adsorption of cadmium ions from aqueous solution by means of olive cake. J. Hazard. Mater., 151: 194-201. DOI: 10.1016/j.jhazmat.2007.05.069

Ali, M., A.M. Emsley, H. Herman and R.J. Heywood, 2001. Spectroscopic studies of the ageing of cellulosic paper. Polymer, 2893-2900. http://cat.inist.fr/?aModele $=$ afficheN\&cpsidt $=868314$

Amarasinghe, B.M.W.P.K. and R.A. Williams, 2007. Tea waste as a low cost adsorbent for the removal of $\mathrm{Cu}$ and $\mathrm{Pb}$ from wastewater. Chem. Eng. J., 132: 299-309.

http://cat.inist.fr/?aModele $=$ afficheN\&cpsidt $=18829529$

Amuda, O.S., A.A. Giwa and I.A. Bello, 2007. Removal of heavy metal from industrial wastewater using modified activated coconut shell carbon, Biochem. Eng. J., 36: 174-181. DOI: 10.1016/bej.2007.02.013

Awofulu, R.O. and O.J. Okonkwo, 2005. Application of chelest fiber iry (aminopolycarboxylic acid-type cellulose) to the extraction of cadmium ions from aqueous solution. Fresenius Environ. Bull., 14: $732-736$.

http://www.psp-parlar.de/pdf/F_25_095_pp732_736.pdf

Banerjee, K.., G.L. Amy, M. Prevost, S. Nour, M. Jekel, P.M. Gallapgher and C.D. Blumenschein, 2008. Kinetic and thermodynamic aspects of adsorption of arsenic onto Granular Ferric Hydroxide (GFH). Water Res., 42: 3371-3378. DOI: 10.1016/j.watres.2008.04.019

Benaissa, H., 2006. Screening of new sorbent materials for cadmium removal from aqueous solutions. J. Hazard. Mater., B132: 189-195. DOI: 10.1016/j.jhazmat.2005.07.085

Chauhan, G., S.C. Jaswal and M. Verma, 2006. Post fictionalization of carboxymethylated starch and acrylonitrile based networks through amidoximation for use as ion sorbents. Carbohydrate Polymers, 66: 435-443. DOI: 10.1016/j.carbpol.2006.03.030

Choi, J., Lee, J.Y. and J.S. Yang, 2008. Biosorption of heavy metals and uranium by starfish and Pseudomonas putida. J. Hazard. Mater., 161: 157-162. DOI: 10.1016/j.jhazmat.2008.03.065

Demirbas, A., 2008. Heavy metal adsorption onto agro-based waste materials: A review. J. Hazard. Mater., 157: 220-229. DOI: 10.1016/j.jhazmat.2008.01.024
Doyurum, S. and A. Çelik, 2006. Pb(II) and $\mathrm{Cd}(\mathrm{II})$ removal from aqueous solutions by olive cake. J. Hazard. Mater., B., 138: 22-28. DOI: 10.1016/j.jhazmat.2006.03.071

Feng, D. and C. Aldrich, 2004. Adsorption of heavy metals by biomaterials derived from the marine alga Ecklonia maxima. Hydrometallurgy, 73: 1-10. DOI: 10.1016/S0304-386X(03)00138-5

Gardea-Torresdey, J., M. Hejazi, K. Tiemann, J.G. Parsons, M. Duarte-Gardea and J. Henning, 2002. Use of hop (Humulus lupulus) agricultural by-products for the reduction of aqueous lead(II) environmental health hazards. J. Hazard. Mater., B91: 95-112.

Guibal, E., 2004. Interactions of metal ions with chitosan-based sorbents: A review. Seperat. Purificat. Technol., 38: 43-74. DOI: 10.1016/jseppur.2003.10.004

Hinterstoisser, B., M. Åkerholm and L. Salmén, 2001. Effect of fibre orientation in dynamic FTIR study on native cellulose. Carbohydrate Res., 334: 27-37. DOI: 10.1016/S0008-6215(01)00167-7

Ho, Y.S., W.T. Chiu, C.S. Hsu and C.T. Huang, 2004. Sorption of lead ions from aqueous solution using tree fern as a sorbent. Hydrometallurgy, 73: 55-61. DOI: 10.1016/j.hydromet.2003.07.008 http://www.ncbi.nlm.nih.gov/pubmed/11900908

Igwe, J.C., E.C. Nwokennaya and A.A. Abia, 2005. The role of $\mathrm{pH}$ in heavy metal detoxification by biosorption from aqueous solutions containing chelating agents. Afr. J. Biotechnol., 4: 1109-1112. http://academicjournals.org/ajb/PDF/Pdf2005/Oct/I gwe\%20et\%20al.pdf

Keskinkan, O., M.Z.L. Goksu, M. Basibuyuk and H.C.F. Forster, 2004. Heavy metal adsorption properties of a submerged aquatic plant (Ceratophylum demersum). Bioresour. Technol., 92: 197-200. DOI: 10.1016/j.biortech.2003.07.011

Kim, D.S., 2004. $\mathrm{Pb}^{2+}$ removal from aqueous solution using crab shell treated by acid and alkali. Bioresour. Technol., 294: 345-348. DOI: 10.1016/j.biortech.2003.10.030

Kobayashi, M., I. Suzawa and E. Ichishima, 1990. Highly reactive dialdehydes of cellulose and $\alpha-$ cyclodextrin. Agric. Biol. Chem., 54: 1705-1709. http;//nels.nii.ac.jp/els/110006325019.pdf?id

Koivula, M.P., K. Kujala, H. Ronkkomaki and M. Makela, 2009. Sorption of $\mathrm{Pb}(\mathrm{II}), \mathrm{Cr}(\mathrm{III}), \mathrm{Cu}(\mathrm{II}), \mathrm{AS}$ (III) to peat and utilization of the sorption properties in industrial waste landfill hydraulic barrier layers. J. Hazard. Mater., 164: 345-352. DOI: 10.1016/j.jhazmat.2008.08.008 
Kumar, P.A., S. Chakraborty and M. Ray, 2008. Removal and recovery of chromium from wastewater using short chain polyaniline synthesized on jute fiber. Chem. Eng. J., 141: 130-140. DOI: $10.1016 /$ j.cej.2007.11.004

Kumar, U., 2006. Agricultural products and byproducts as a low cost adsorbent for heavy metal removal from water and wastewater: A review. Sci. Res. $\quad$ Essays, 1: 033-037. http:www.academicjournals.org/SRE

Mashitah, M.D., Y.Y. Azila and S. Bhatia, 2007. Biosorption of cadmium(II) ions by immobilized cells of Pycnoporus sanguneus from aqueous solution. Bioresour. Technol., 99: 4742-4748. DOI: 10.1016/j.biortech.2007.09.062

McSweeny, J.D., Rowell, R.M. and S.H. Min, 2006. Effects of citric acid modification of aspen wood on sorption of copper ion. J. Nat. Fibr., 3: 43-58. DOI: $10.1300 / J 395 v 03 n 01 \_05$

Meunier, N., J. Laroulandie, J.F. Blais and R.D. Tyagi, 2003. Cocoa shells for heavy metal removal from acidic solutions. Bioresour. Technol., 90: 255-263. DOI: 10.1016/S0960-8524(03)00129-9

Murathan, A.S. and M. Bütün, 2006. Removal of lead ions from dilute aqueous solution in packed columns by using natural fruit shells through adsorption. Fresenius Environ. Bull., 15: 1491-1498. http://direct.bl.uk/bld/PlaceOrder.do?UIN=199937 237\&ETOC $=$ RN \& from $=$ searchengine

Nagib, S., K. Inoue, T. Yamaguchi and T. Tamaru, 1999. Recovery of Ni from a large excess of Al generated from spent hydrodesulphurisation catalyst using picolylamine type chelating resin and complexane types of chemically modified chitosan. Hydrometallurgy, 51: 73-85. http://cat.inist.fr/?aModele $=$ afficheN\&cpsidt $=1660$ 138

Naiya, T.K., A.K. Bhattacharya and S.K. Das, 2009. Adsorption of $\mathrm{Cd}(\mathrm{II})$ and $\mathrm{Pb}(\mathrm{II})$ from aqueous solutions on activated alumina. J. Colloid. Interface Sci., 333: 14-26. DOI: 10.1016/j.jcis.2009.01.003

Pehlivan, E., B.H. Yanik, G. Ahmetli and M. Pehlivan, 2007. Equilibrium isotherm studies for the uptake of cadmium and lead ions onto sugar beet pulp. Bioresour. Technol., 99: 3520-3527. DOI: 10.1016/j.biortech.2007.07.052

Popuri, S.R., Y. Vijaya, V.M. Boddu and K. Abburi, 2009. Adsorptive removal of copper and nickel ions from water using chitosan coated PVC beads. Bioresour. Technol., 100: 194-199. DOI: 10.1016/j.biortech.2008.05.041
Prasad, M. and S. Saxena, 2007. Attenuation of divalent toxic metal ions using natural sericitic pyrophyllite. J. Environ. Manage., 88: 1273-1279. DOI: 10.1016/j.jenvman.2007.07.013

Rao, R.A.K. and M.A. Khan, 2007. Removal and recovery of $\mathrm{Cu}(\mathrm{II}), \mathrm{Cd}(\mathrm{II})$ and $\mathrm{Pb}(\mathrm{II})$ ions from single and multimetal systems by batch and column operation on Neem Oil Cake (NOC). Seprat. Purificat. Technol., 57: 394-402. DOI: 10.1016/j.seppur.2007.006

Rios, R.R.V., Alves, D.E. and R.M. Lago, 2003. Tailoring activated carbon by surface chemical modification with $\mathrm{O}, \quad \mathrm{S}$ and $\mathrm{N}$ containing molecules. Mater. Res., 6: 129-135. http://www.scielo.br/pdf/mr/v6n2/16013.pdf

Rosa, G., J.L. Gardea-Torresdey, J.R. Peralta-Videa and I. Herrera, 2003. Use of silica immobilized human for heavy metal removal from aqueous solution under flow conditions. Bioresour. Technol., 90: 11-17. DOI: 10.1016/S0960-8524(03)00099-3

Senthilkumaar, S., S. Bharathi, D. Nhithyanandhi and V. Subburam, 2000. Biosorption of toxic heavy metals from aqueous solutions. Bioresour. Technol., 75: 163-165. DOI: S09608524(00)00021-3

Soudais, Y., L. Moga and J. Blazek, 2007. Coupled DTA-TGA-FTIR investigation of pyrolytic decomposition of EVA, PVC and cellulose. J. Anal. Applied Pyrol., 78: 46-57. DOI: 10.1016/j.jaap.2006.04.005

Vaughan, T., C.W. Seo and W.E. Marshall, 2001. Removal of selected metal ions from aqueous solution using modified corn cobs. Bioresour. Technol., $\quad 78$ : 133-139. http://www.ncbi.nlm.nih.gov/pubmed/11333031

Wang, J., D. Zhang, T.R. Lawson and R.A. Bartsch, 2009. Sorption of heavy metal ions by silica gelimmobilized, proton-ionizable calyx[4]arenes. Talanta, 78: 477-483. DOI: 10.1016/j.talanta.2008.11.038

Wong, K.K., C.K. Lee, K.S. Low and M.J. Haron, 2003a. Removal of $\mathrm{Cu}$ and $\mathrm{Pb}$ from electroplating wastewater using tartaric acid modified rice husk. Process Biochem., 39: 437-445. DOI: 10.1016/S0032-9592(03)00094-3

Wong, K.K., C.K. Lee, K.S. Low and M.J. Haron, 2003b. Removal of $\mathrm{Cu}$ and $\mathrm{Pb}$ by tartaric modified rice husk from aqueous solutions. Chemosphere, 50: 23-28. DOI: S004 5-6535(02)00598-2

Yurtsever, M. and I.A. Sengil, 2009. Biosorption of $\mathrm{Pb}$ (II) ions by modified quebracho tannin resin. J. Hazard. Mater., 163: 38-64. DOI: 10.1016/j.jhazmat.2008.06.077 
Zvinowanda, C.M., J.O. Okonkwo, N.M. Agyei and P.N. Shabalala, 2008a. Preparation and characterisation of biosorbents made from tassel. Canadian J. Pure Applied Sci., 2: 476-480. http://www.cjpas.net/previous_issue.pdf

Zvinowanda, C.M., J.O. Okonkwo, N.M. Agyei, P. Forbes and V. Mpangela et al., 2008b. Biosorption of toxic metals: The potential use of maize tassel for the removal of $\mathrm{Pb}(\mathrm{II})$ from aqueous solutions. Fresenius Environ. Bull., 17: 814-818.

Zvinowanda, C.M., J.O. Okonkwo, N.M. Agyei and P.N. Shabalala, 2009a. Physicochemical characterization of maize tassel adsorbent: Part I. Surface texture, microstructure and thermal stability. J. Applied Poly. Sci., 111: 1923-1930. DOI: 10.1002/app.29213
Zvinowanda, C.M., J.O. Okonkwo, N.M. Agyei, M.M. Sekhula and R. Sadiku, 2009b. Application of maize tassel for the removal of $\mathrm{Pb}, \mathrm{Se}, \mathrm{Sr}, \mathrm{U}$ and $\mathrm{V}$ from borehole water contaminated with mine wastewater in the presence of alkaline metals. J. Hazard. Mater., 164: 884-891. DOI: 10.1016/j.jhazmat.2008.08.110

Zvinowanda, C.M., J.O. Okonkwo, N.M. Agyei and P.N. Shabalala, 2009c. A novel adsorbent for heavy metal remediation in aqueous environments. Int. J. Environ. Sci. Technol., 6: 425-434. http://www.ceers.org/ijest/issues/abstract_result.as $\mathrm{p} ? \mathrm{ID}=603011$ 